\title{
L 86-33 Sweetpotato Germplasm
}

\author{
L.H. Rolston', D.R. La Bonte', W.A. Mulkey ${ }^{3}$, C.A. Clark ${ }^{4}$, \\ J.M. Cannons, and P.W. Wilson ${ }^{6}$ \\ Louisiana Agricultural Experiment Station, Louisiana State University \\ Agricultural Center, Baton Rouge, LA 70803
}

Additional index words. Ipomoea batatas, vegetable breeding, disease resistance

L 86-33 sweetpotato [Ipomoea batatas (L.) Lam.] was developed by the Louisiana Agricultural Experiment Station. This breeding line has a unique combination of disease resistance and high yield and excellent baking and processing qualities.

\section{Origin}

L 86-33 originated from the breeding program of L.H. Rolston as an open-pollinated seedling of L, 82-508, 'Beauregard', poly crossed in 1985. The female lineage of L 82508 is L 78-21. L 78-21 originated from L 70197.

\footnotetext{
Received for publication 24 May 1993. Accepted forpublication19Nov.1993. Approved forpublication by the Director of the Louisiana Agricultural Experiment Station as manuscript no. 93-28-7123. Supported by state and matching funds allocated to the Louisiana State Univ. Agricultural Center and the Louisiana Sweet Potato Advertising and Development Commission. The cost of publishing this paper was defrayed in part by the payment of page charges.Under postal regulations, this paper thereforemustbehereby marked advertisement solely to indicatethisfact.

${ }^{1}$ Professor,Dept. of Entomology.

${ }^{2}$ AssistantProfessor,Dept.ofHorticulture,towhom reprintrequests should be addressed.

${ }^{3}$ ResidentDirector,SweetPotato Research Station, P.O. Box 120, Chase, LA 71324.

${ }^{4}$ Professor,Dept.ofPlantPathologyandCropPhysiology.

${ }^{5}$ Specialist (Horticulture), Louisiana Cooperative Extension Service.

${ }^{6}$ AssociateProfessor,Dept.of Horticulture.
}

\section{Description}

L 86-33 has moderately long greenstemmed vines and a dense canopy, similar to that of 'Jewel'. Leaves are cordate, dark green with light purple adaxial and purple abaxial veination. The petiole is purple at the base and at the junction with the leaf axis. Storage roots are long, elliptic, and smooth with light-red skin that is lighter than that of 'Red Glow' and darker than that of 'Beauregard'. The cortex is thin $(2.5$ to $3.0 \mathrm{~mm})$, and the flesh is uniform deep orange. Dry matter concentration is $24 \%$, $26 \%$ for 'Jewel'. Baking and canning qualities are similar to those of 'Jewel' (1990, 1991, 1992 National Sweetpotato Collaborators regional trials). Flowering and seed set are moderate, similar to those of 'Beauregard'.

\section{Disease and insect resistance}

L 86-33 has a resistant reaction to fusarium wilt [Fusarium oxysporum Schlect. f. sp. batatas (Wallenw.) Snyd \& Hans], similar to that of 'Goldrush'. Reaction to southern rootknot nematode [Meloidogyne incognita (Kofoid and White) Chitwood] is intermediate, slightly less resistant than 'Jewel' and superior to that of 'Beauregard'. It is resistant to soil rot [Streptomyces ipomoea (Person \& W.J. Martin) Waksman \& Henrici]; the reaction is superior to that of 'Beauregard'. Yield and shape are not affected by severe soil rot conditions. L 86-33 does not show symptoms to the viral disease internal cork. Storage roots are resistant to bacterial root rot (Erwinia chrysanthemi Burkholder, McFadden, \& Dimock), superior to 'Jewel'. Storage roots are resistant to fusarium root rot caused by Fusarium solani (Sacc.) Mart. emend. Snyd.
\&Hans., similar to 'Beauregard' and superior to 'Jewel'.

L 86-33 is susceptible to both white grub species, Plectris aliena Chapin (1992 National Sweetpotato Collaborators regional trials) and Phyllophaga ephilida (Say.), similar to 'Jewel'. It is similar to 'Jewel' in susceptibility to the banded cucumber beetle (Diabrotica balteata Leconte). It is susceptible to the sweetpotato flea beetle (Chaetoncnema confinis Crotch) when compared with resistant controls 'Regal' and 'Excel' (1992 National Sweetpotato Collaborators regional trials). Susceptibility to the wireworms, Diabrotica, Systena complex, is similar to that of 'Jewel,' 'Centennial', and 'Vardaman' (1990, 1991, and 1992 National Sweetpotato Collaborators regional trials).

\section{Plant production, root quality, and yield}

L 86-33 has been evaluated for plant production, root quality, and yield in the National Sweetpotato Collaborators regional trials for 3 years. Plant production, uniformity of emergence, and earliness of plants in root beds is inferior to that of 'Beauregard' and 'Jewel' (1990, 1991, and 1992 National Sweetpotato Collaborators regional trials). L 86-33 retains its deep orange flesh up to 10 months in storage at $15 \mathrm{C}$ and is not a precocious sprouter in storage. L 86-33 requires 110 to 120 growing days, similar to 'Jewel'. Yield of L 86-33 was superior to that of 'Jewel' and similar to that of 'Beauregard' (1990, 1991, and 1992 National Sweetpotato Collaborators regional trials); however, the U.S. \#1 grade roots (5.1 to $8.9 \mathrm{~cm}$ in diameter; 7,6 to $22.9 \mathrm{~cm}$ long) are more elongate than those of 'Beauregard' (15 to $18 \mathrm{~cm}$ vs. 12 to $16 \mathrm{~cm}$ ) and less marketable, particularly when grown in light-textured soils. In 30 test plots in Louisiana, L 86-33 produced $13 \%$ less (by weight) U.S. \#1 grade roots when compared to 'Beauregard'.

\section{Availability}

Limited quantities of seed stock will be available for free distribution to researchers upon written request to the Sweet Potato Research Station, P.O. Box 120, Chase,LA71324 or the Southern Regional Plant Introduction Station, 1109 Experiment St., Griffin, GA 30223. 